\title{
TARAXACUM KOK-SAGHYZ (ASTERACEAE, СОМРОSITAE) - ИСТОЧНИК ЦЕННОГО РАСТИТЕЛЬНОГО СЫРЬЯ ДЛЯ РЕЗИНОВОЙ, ПИЩЕВОЙ И ФАРМАЦЕВТИЧЕСКОЙ ПРОМЫШЛЕННОСТИ
}

С.Н. Кутузова, Н.Б. Брач, Н.Г. Конькова, В.А. Гаврилова* Всероссийский институт генетических ресурсов растений имени Н.И. Вавилова

* Эл.noчma:v.gavrilova@vir.nw.ru

Статья поступила в редакиию 17.12.2014; принята к печати 10.10.2015

В обзоре изложены история открытия кок-сагыза (Taraxacum kok-saghyz Rodin) и перспективы и экономическая выгода его возделывания. Приведены биологические особенности, ботаническое описание, результаты цитологического и биохимического изучения растения, свойства получаемых из этого растения латекса, каучука и инулина. В корнях кок-сагыза содержится от 4 до 11\% каучука (в отдельных корнях обнаружено до 23\%), по качеству не уступаюего каучуку из гевеи, а также до 45\% инулина. Натуральный каучук применяют в производстве шин для самолетов, скоростных и большегрузных автомашин. Латекс используется для изготовления гипоаллергенных перчаток и других резиновых изделий специального назначения. Инулин - источник сырья для пищевой и фармацевтической промышленности и может быть преобразован в этанол для использования в качестве биотоплива. Кроме этого в корнях кок-сагыза обнаружен углеводород сквален - ценное косметическое сырье.

Ключевые слова: Taraxacum kok-saghyz, латекс, каучук, инулин, сквален.

TARAXACUM KOK-SAGHYZ (ASTERACEAE, COMPOSITAE) AS A SOURCE OF VALUABLE RAW MATERIALS FOR RUBBER, FOOD, AND PHARMACEUTICAL INDUSTRIES

S.N. Kutuzova, N.B. Brach, N.G. Kon'kova, V.A. Gavrilova*

N.I. Vavilov All-Russia Institute of Genetic Resources of Plants E-mail:v.gavrilova@vir.nw.ru

The review describes the history of discovery of kok-saghyz (Taraxacum kok-saghyz Rodin) and the prospects for and benefits of its cultivation. The biological features, botanical characterization, the results of cytological and biochemical studies of kok-saghyz, and the properties of latex, rubber, and inulin derived from this plant are presented. The roots of kok-saghyz contain 4 to $10 \%$ of rubber resin (in some roots, up to $23 \%$ is found), which is not inferior to the product derived from rubber tree, and up to $45 \%$ of inulin. Natural rubber is usable in manufacturing of tires for airplanes and high-speed and heavy-load vehicles. Latex is used to manufacture hypoallergenic gloves and other special-purpose articles. Inulin is a raw material for food and pharmaceutical industries and is easily fermented into ethanol to be used as a biofuel. Squalene found in the roots of kok-saghyz is usable in cosmetics.

Keywords: Taraxacum kok-saghyz, latex, rubber, inulin, squalene.

\section{Значение натурального каучука и необходимость использования альтернативных культур}

В промышленном производстве всего мира огромным и все возрастающим спросом пользуется натуральный каучук. Этот уникальный биополимер не может быть заменен синтетическими аналогами в большинстве сфер использования без ущерба для качества продукции и поэтому имеет огромное экономическое значение. Единственным экономически значимым источником промышленного натурального каучука (цис-1,4-полиизопрена) в настоящее время является гевея бразильская, которая произрастает в странах с тропическим климатом. В США импорт сырого латекса занимает второе место после нефти. В Западной Европе и других промышленно развитых странах ситуация аналогична. На основе каучука производят 40000 различных товаров, к которым относятся изделия, используемые в промышленно- сти, автомобилестроении, медицине, производстве обуви и адгезионных материалов.

В настоящее время мировое производство натурального каучука переживает кризис. В результате гибели от болезней большей части плантаций гевеи на Американском континенте возделывание этого растения сосредоточилось в трех южно-азиатских странах - Малайзии, Индонезии и Таиланде. В латексе гевеи недавно были обнаружены специфические белки, вызывающие у человека аллергию. Простые и дешевые методы удаления данного белка в настоящее время отсутствуют. Каучук гевеи, применяемый в виде латекса в изделиях медицинского назначения, вызывает аллергические реакции от умеренных до сильных. Число таких случаев возросло в последние годы до 1-6\% населения в среднем и до $17 \%$ работников здравоохранения [50]. Новый стандарт США ограничивает содержание белка 200 мкг на грамм сухой массы латекса и требует неопределяемого количества аллергенного белка в латексе. Это стиму- 
лирует производство латекса, свободного от белка и получаемого из альтернативных источников.

Из одних только этих проблем следует необходимость поиска альтернативных источников натурального каучука. В Европе возможно введение в культуру новых каучуконосных растений - гваюлы (Parthenium argentatum Gray) и кок-сагыза (Taraxacum kok-saghys Rodin). Гваюла считается наиболее пригодной для выращивания в Средиземноморских областях, тогда как кок-сагыз может быть использован параллельно с гваюлой в северных и восточноевропейских странах [70].

Каучук кок-сагыза по качеству не уступает каучуку гевеи и даже превосходит его при использовании в шинах тяжелых машин [71]. Другое очень важное направление использования кок-сагыза - производство защитных латексных перчаток для медицинских целей. Иммунологический анализ с использованием специфических антител к главным аллергенам гевеи не показал никакой их активности, что указывает на хорошую перспективу использования латекса коксагыза в медицинских продуктах.

\section{История открытия и выращивания кок-сагыза}

Проблема поиска альтернативного гевее источника натурального каучука возникла в Европе и США перед началом и во время Второй мировой войны. В СССР в 1930-е гг. были обследованы большие территории, осуществлялся интенсивный поиск местных видов растений, обладающих способностью синтеза каучука. Были организованы многочисленные экспедиции. Двухлетнее изучение 1048 видов из 316 родов и 95 семейств отечественной флоры показало, что 609 видов синтезируют каучук и каучукоподобные вещества [13].

Выявленные каучуконосы исследовали во Всесоюзном (ныне Всероссийском) научно-исследова- тельском институте растениеводства (ВИР) с точки зрения введения их в культуру: проводили географические посевы, всесторонне изучали перспективные виды. Опыты показали, что наиболее выгодным является выращивание кок-сагыза [4] (рис. 1).

Кок-сагыз как источник латекса был открыт в 1932 г. в долинах Тянь-Шаня и описан ботаником Л.Е. Родиным. Это эндемичный вид Казахстана. Естественное произрастание его ограничено довольно небольшой территорией (до 10 тыс. км²) в основном в трех межгорных долинах на юго-востоке Алма-Атинской области: Кегенской, Сарджасской, Текесской, отчасти Каркаринской, Челдысуйской и Ащиллы. Долины вытянуты с северо-запада на юго-восток на высоте 1800-2100 м над уровнем моря. Развитие кок-сагыза происходит в суровых условиях резко континентального климата на засоленных почвах, при недостатке влаги и сильных ветрах [25]. Масса сухого корня в естественных зарослях составляет около 1 г [46]. Содержание каучука в растениях естественных зарослей колебалось от 6 до 24\% массы сухого корня [15]. По данным других исследователей оно достигало 10-27\% $[26,32]$. Испытания в культурных условиях не выявили существенных различий у растений из разных урочищ по массе растений и семенной продуктивности. Однако в пределах каждого урочища был обнаружен ряд генотипически различных растений, весьма резко отличающихся по форме листовой пластинки, толщине и массе корня, вегетативному ритму (цветение в первый или второй годы жизни), семенной продуктивности и каучуконосности. Яровизация семян (при 0-3 ${ }^{\circ} \mathrm{C}$ ) выявила среди кок-сагыза 3 различные формы, отличающиеся реакцией на понижение температуры: 1) формы, цветущие в первый год без температурного воздействия; 2) формы, цветущие в первый год при воздействии пониженными температурами; 3) формы, не цветущие в первый год даже при воздействии пониженными температурами [22]. Внутри этих форм

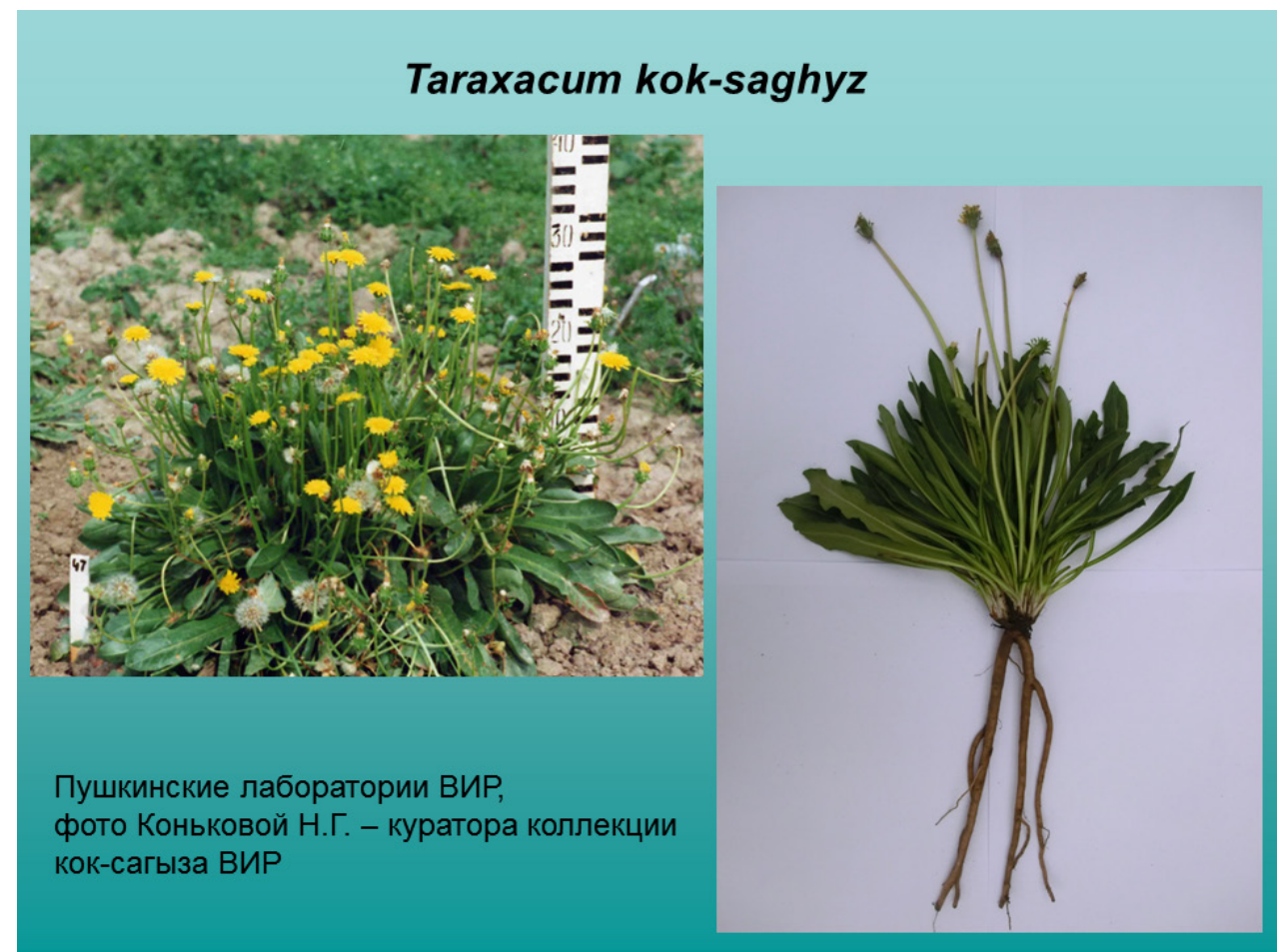

Рис. 1. Кок-сагыз из коллекции ВИР (Всероссийского института генетических ресурсов растений имени Н.И. Вавилова) 
обнаружены морфо-биологические типы кок-сагыза, различающиеся по времени зацветания, скороспелости и другим признакам [17, 31].

На основе семян кок-сагыза, собранных в естественных зарослях, началось всестороннее изучение растения. Проведено ботаническое описание и определение внутривидового разнообразия растений, позволившее отобрать лучшие генотипы для окультуривания [17]. Изучены биологические и морфологические особенности растения [12, 18, 22]. Было установлено, что культура влаголюбива, требует не менее 420-600 мм осадков в год с их равномерным распределением, нуждается в высокоплодородных почвах - поймы рек, окультуренные торфяники, черный пар. Определены лучшие районы для его внедрения, разрабатывалась агротехника культуры на различных типах почв, изучены болезни и вредители [21, $26,34,45]$. Проводилась селекционная работа [5, 31].

В это же время в стране велась интенсивная работа по созданию синтетического каучука. Однако первый синтетический каучук, полученный на основе полимеризации 1,3-бутадиена, по качеству сильно уступал натуральному. Добавление натурального каучука в синтетический делало последний более выносливым и более упругим. Из него изготовляли шины для разных колесных машин, товары народного потребления.

Кок-сагыз в нашей стране выращивали до середины 1950-х гг. Эти работы были прекращены после открытия способа синтеза цис-изопренового каучука, по своему строению и физико-химическим свойствам почти идентичного натуральному. Семена дикорастущих зарослей, а также созданных в различных регионах страны сортов и местных плантационных популяций были переданы в ВИР. Коллекция насчитывает 128 образцов. Изучение представителей плантационных популяций из разных регионов в условиях Пушкинских лабораторий ВИР показало, что в коллекции имеется широкое разнообразие генотипов по морфологическим и хозяйственно ценным признакам и содержанию каучука от 4 до $11 \%$ [7, 9]. При индивидуальном анализе выращенных в Пушкинских лабораториях ВИР корней, проведенном на кафедре химии и технологии каучука и резины Санкт-Петербургского технологического института методом экстрагирования хлороформом в аппарате Сокслета, в лучших по содержанию каучука корнях оно достигало 23\% [20]. Описаны болезни и вредители культуры [8]. В настоящее время вся коллекция заложена на длительное хранение.

В США технико-экономическое обоснование производства кок-сагыза было составлено в 1942-1944 гг. как часть Чрезвычайного каучукового проекта, разработанного Конгрессом США в ответ на нехватку каучука в период Второй мировой войны. Семена кок-сагыза были получены из СССР, выращивали его для выпуска шин [71]. Кроме США начали выращивать кок-сагыз Италия, Великобритания [48], Швеция, Австралия, Аргентина, Северный Китай и Германия [56]. Лучшие поля США производили приблизительно 110 кг/га каучука, лучшие российские урожаи были 200 кг/га. Однако выращивание кок-сагыза было очень трудоемким и дорогим. После войны дешевый каучук из гевеи снова стал доступным, и во всех странах программы по производству каучука из кок-сагыза были прекращены.
В настоящее время новые эколого-экономические условия заставляют снова обратиться к незаслуженно забытой культуре кок-сагыза. В США исследовательские центры университета штата Огайо совместно с другими университетами и партнерами в промышленности с 2005 г. на базе совместных грантов разрабатывают основы использования кок-сагыза в качестве нового источника получения натурального каучука. По предварительным оценкам экспертов, 12 тыс. км2 площадей, засеянных кок-сагызом, обеспечат 30\% годовой потребности США в натуральном каучуке. Для сравнения: в 2007 г. только в штате Огайо различными культурами было засеяно около 56 тыс. км ${ }^{2}$ площадей. Предварительная стоимость

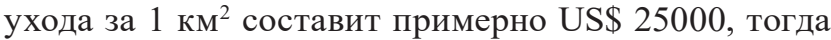
как выращивание цветов и продовольственных культур обходится почти в три раза дороже. Дополнительные доходы принесет продажа инулина. На данный момент США на сто процентов зависят от импорта натурального каучука из юго-восточной Азии. Европейские страны работают над проектом EU-based Production and Exploitation of Alternative Rubber and Latex Sources (EU-PEARLS), направленным на многостороннее изучение и внедрение в производство кок-сагыза и гваюлы [69].

\section{Биологические особенности кок-сагыза и его ареал}

Кок-сагыз - многолетнее травянистое растение, относится к семейству Asteraceae, внешне мало отличается от обыкновенного одуванчика T. officinale. Корень стержневой, глубоко проникающий в почву, покрыт черной или бурой корой. При надломе коры и очищении наружного слоя пробки заметны эластичные нити каучука. Стебель сильно укороченный (каудекс), несет распластанную по земле розетку из многочисленных сизых, сизовато-зеленых или зеленых голых листьев, чрезвычайно варьирующих по размерам и форме: лопатчатых, обратно-яйцевидных, широко-ланцетных, от цельнокрайних до выемчато-зубчатых. Из центра розетки выходят 3-10 округлых, полых, тонких, разновременно развивающихся цветоносов; соцветие - корзинка средней величины (1,1-2,0 см в диаметре), цветки лимонно-желтые. Цветение одного растения продолжается 17-30 дней, период созревания семянок длится 15-18 дней. Семянки снабжены летучками из белых волосков [25]. Кок-сагыз - мезофит, то есть довольно влаголюбивое растение. В случае засухи он может перейти в состояние покоя. Семена обладают длительным периодом покоя, поэтому для их дружного прорастания необходима стратификация при температуре $0-1^{\circ} \mathrm{C}$ [34]. Оптимальная температура прорастания семян находится в пределах $25-30{ }^{\circ} \mathrm{C}$. Семена, прошедшие стратификацию, прорастают за 6-8 дней, нестратифицированные - за 40-60 дней [35, 36, 46].

Кок-сагыз в отличие от других видов рода Taraxacum, в том числе одуванчика обыкновенного, которым свойствен партеногенез, является типичным перекрестником. Опылителями являются насекомые. Возможна его естественная гибридизация с видами, нормальными в половом отношении (T. multiscaposum, T. karatavicum и др.), гибриды с которыми по габитусу не отличаются от кок-сагыза, но содержат только следы каучука. Гибридизация кок-сагыза с T. officinale могла бы быть полезной 
в плане повышения мощности развития, толщины корня, плодовитости, партеногенеза, но оказалась невозможной [16]. Все партенокарпические одуванчики являются полиплоидами с числом хромосом 24 , 32,40 или 48, большинство имеет $2 \mathrm{n}=24$, то есть являются триплоидами. Число хромосом у кок-сагыза, по форме тождественных другим видам одуванчиков с нормальным половым процессом, равно 16 [33]. Некоторые ученые в последнее время стали ошибочно отождествлять T. kok-saghyz Rodin с $T$. brevicorniculatum Koroleva, который часто смешивается с кок-сагызом в природе и засоряет его культурные плантации. В отличие от T. kok-saghyz, T. brevicorniculatum имеет 24 хромосомы и размножается только с помощью апомиксиса.

Относительно флоры Китая есть предположение, что T. brevicorniculatum является триплоидом гибридного происхождения от скрещивания $T$. koksaghyz с другим видом Taraxacum. Однако всестороннее сравнение T. kok-saghyz и T. brevicorniculatum, включавшее AFLP анализ ДНК, показало, что $T$. brevicorniculatum является триплоидным клоном $T$. kok-saghyz [60]. Согласно этим исследованиям, большинство образцов кок-сагыза, сохраняемых в ботанических садах и генбанках еx situ, являются на самом деле T. brevicorniculatum, и большая часть современных научных публикаций посвящена как раз T. brevicorniculatum, а не T. kok-saghyz. В то же время коллекция ВИР, не участвовавшая в описанном выше исследовании, представлена в основном образцами диплоидного кок-сагыза.

Окультуривание кок-сагыза было начато в районах Средней Азии, вблизи мест его естественного произрастания. Однако высокие температуры весной и летом, недостаток влаги и низкая относительная влажность воздуха вызывали уже на первом году жизни перерыв в росте кок-сагыза, ограничивая период его активной вегетации 2,5 месяца. В этих условиях растения давали низкие урожаи корней с незначительным содержанием каучука. Географические посевы, проведенные ВНИИ каучуконосов, показали, что кок-сагыз в условиях России может расти повсеместно - от западных границ до Амурского края и от Архангельска до южных областей. Наиболее высокие урожаи получали в центральных областях России и в Белоруссии $[10,14,46]$. В условиях хороших плантаций у окультуренных форм масса корня растений, полученных из семян, достигает 150-200 г, а из черенков - 250-300 г и более [46]. В среднем содержание каучука у возделываемых сортов было около 15\% массы сухого корня [61]. Считается, что в свободно опыляющихся посевах оно увеличится [68]. Селекционным путем содержание каучука может быть доведено до 25\% [65]. Предполагается, что при гибридизации с T. officinale, имеющим крупные корни, можно получить гибриды с содержанием каучука $20 \%$, теоретически может быть получен урожай каучука до 1800 кг/га [63].

\section{Латекс}

Латекс (от латинского latex: жидкость, сок) - млечный сок. В растении он образуется в специализированных трубковидных анастомозных клеточных системах, расположенных в цитоплазме клетки [66]. У кок-сагыза он молочно-белого цвета, представляет собой полидисперсную систему. В ней разнообраз- ные каучуковые частицы (глобулы) являются дисперсной фазой, а серум (водный раствор различных веществ) - дисперсионной средой. О развитии глобул очень мало известно, вероятно потому, что мелкие, доступные только электронной микроскопии латексные глобулы нельзя с достоверностью отличить от других маленьких частиц в цитоплазме [49]. Глобулы имеют шарообразную форму, их размер колеблется в широких пределах. В латексе однолетних растений кок-сагыза глобулы с диаметром до $0,5 \mu$ составляют $68,4 \% ; 0,6-1,0 \mu-27,9 ; 1,1-1,5 \mu-2,7 ; 1,6-3,0 \mu-1,0 \%$. [37]. В первые фазы развития глобулы почти не поддаются измерению, к концу вегетации их диаметр достигает 1,5-2,0 $\mu$ [3]. Если средний размер глобул кок-сагыза принять равным $0,5 \mu$, а содержание каучука в латексе $-35 \%$, то можно подсчитать, что в 1 см3 латекса содержится 630 млрд каучуковых глобул [41]. В 1 см3 латекса гевеи с содержанием каучука 38$40 \%$ содержится 640 млрд частиц каучука. Все частицы находятся в броуновском движении, перемещаясь в пространстве со средней скоростью 12 мкм/с [62].

Латекс корней однолетних растений содержит 30$35 \%$ каучука, от 6 до 15,5\% некаучуковых веществ (смолистые вещества, дисахара, инулин и др.) и 50$60 \%$ воды [39]. Некоторые вещества образуют в водной среде латекса истинные растворы (минеральные соли, сахара), другие - коллоидные растворы (белки, соли жирных кислот и др.), а также в известной мере адсорбируются поверхностью глобул. Таким образом, латекс является многокомпонентной и полидисперсной системой.

В сухом остатке латекса содержится $82,5 \%$ каучука, $8,9 \%$ смол, 3,9\% моноз, $0,4 \%$ сахарозы, $0,08 \%$ инулина, 4,22\% белков, золы и пр. Содержание сухого вещества увеличивается с возрастом растения. Так в фазу розетки у однолетних растений оно составляло $43,1 \%$, во время плодоношения $-45,1$, а перед уходом в зимовку $-62,1 \%[38,41]$.

Глобулы латекса имеют сложное строение. Наружный слой образован белками, липидами, жирными кислотами и другими поверхностно-активными веществами, содержащимися в латексе. Следующий слой состоит из твердого эластичного каучука. Наконец, внутренняя часть глобулы - основная ее масса - представляет собой также каучуковый углеводород, по консистенции напоминающий очень вязкую жидкость [55].

Исследования структуры латексных глобул и их биохимических компонентов позволяют предположить, что они формируются в шероховатом эндоплазматическом ретикулуме. Полная структура глобул сходна у всех видов каучуконосных растений, исследованных в настоящее время. Они содержат гомогенное латексное ядро, окруженное однослойной мембраной [52]. Переход от текучего содержимого внутренней части глобулы к эластичному каучуку второго слоя происходит постепенно. Различие между тем и другим, по-видимому, заключается в степени полимеризации каучукового углеводорода или, возможно, даже в некоторых особенностях молекулярной структуры. Текучее содержимое глобул состоит главным образом из растворимого золь-каучука, а эластичный слой - из гель-каучука. Наличие в глобулах латекса золь-каучука обусловливает возможность слияния отдельных глобул в более крупные частицы. 
Латексные глобулы заполняют васкулярные пучки по всему растению [57], но каучук получают из корней, которые содержат самое большое его количество - 10,6\% и более, в листьях его менее $1 \%$, в каудексах - 2,7\%. Каучуконосность растения зависит от числа и размера млечных трубок, а также от насыщенности млечного сока каучуком. Известно, что с возрастом растения концентрация каучука в млечном соке повышается. К концу вегетационного периода она возрастает в 3,3 раза по сравнению со временем бутонизации [47]. В процессе роста происходит увеличение диаметра млечных сосудов, то есть их емкости. Общая площадь поперечного сечения млечных сосудов двухлетних растений гораздо больше, чем однолетних. Разные зоны корня содержат разное число млечных трубок. Наиболее насыщены млечниками зоны, удаленные от корневой шейки на 12-25 см, боковые корни содержат не меньше каучука, чем главный. По мере старения млечных трубок растет молекулярный вес образующегося в них каучука и достигает максимума к началу зимнего периода [29]. При их отмирании происходит коагуляция млечного сока, глобулы сливаются вместе, образуя сплошную гомогенную массу. Каучук переходит в нерастворимое состояние, образуя трехмерные макромолекулы $[40,42]$.

\section{Физические свойства латекса}

Плотность каучука принимается равной 914 кг/м³ , а


нем содержании каучука в латексе около $35 \%$ плотность его колеблется в пределах от 974 до 980 кг/. ${ }^{3}$. С увеличением концентрации латекса его вязкость возрастает вначале медленно, а начиная с 50-60\%значительно быстрее. Латекс концентрацией 65-75\% представляет собой густую пасту. Одним из преимуществ латекса перед растворами каучука является его способность смачивать гидрофильные поверхности (кожу, ткань и т. д.). Поскольку латекс содержит большое количество поверхностно-активных веществ (жирных кислот, белков и т. д.), его поверхностное натяжение значительно ниже, чем у воды. Для свежего латекса оно составляет $38 \times 10^{3}-40 \times 10^{3} \mathrm{H} / \mathrm{M}$. Смачивающая и пропитывающая способность латекса обычно возрастает с понижением его поверхностного натяжения. Благодаря наличию поверхностного слоя, состоящего в основном из белков и липидов, глобулы имеют электрический заряд, величина и знак которого зависят от реакции среды и характера диссоциации его протеиновой части. Свежий латекс обладает слегка щелочной реакцией $(\mathrm{pH}=7,2)$; глобулы заряжены отрицательно. Электрокинетический потенциал глобул равен 35-40 мВ и линейно возрастает с повышением $\mathrm{pH}$. Изоэлектрическая точка лежит в пределах $\mathrm{pH}$ 3-5 [http://www.center-politeh.ru/ developments/kauchuk.html].

Консервативность природы компонентов биомембраны определенной латексной глобулы позволяет предположить, что генерация латексной частицы зависит от небольшого числа специфических генов. У всех видов каучуконосов есть очень крупные белки или белковые комплексы, содержащие интегрированный, связанный с мембраной, синтезирующий каучук фермент цис-пренилтрансферазу или ферментный комплекс каучуктрансферазу (ЕС 2.5.1.20). Этот комплекс синтезирует каучук из гидрофильного субстрата, поступающего из цитоплазмы, и гидрофоб- ного полимера, находящегося в латексной частице. Реакция полимеризации видимо проходит на поверхности частицы $[52,64,66]$.

В промышленности латекс используют для получения натурального каучука и в качестве самостоятельного продукта для непосредственного изготовления из него различных изделий: тонкослойных «маканых» (в т. ч. медицинских) перчаток и губчатых изделий, нитей и других разнообразных технических и бытовых резиновых изделий. Латекс применяется вместо резиновых клеев - растворов каучука в бензине или бензоле. Замена клеев латексом помимо экономии растворителя устраняет пожароопасность производства, улучшает условия труда, а иногда повышает качество изделий. При получении и переработке латекса энергозатраты и загрязнение среды обитания минимальны. Изделия из латекса обладают хорошими физикомеханическими свойствами. Техническое применение латекса возрастает с каждым годом. В 1922 г. его мировое потребление составляло 420 т, в 1978 г. оно достигло 281 тыс. т, а в 1980-х гг. - 300-320 тыс. т/год (7-8\% потребления натурального каучука) [64].

\section{Каучук}

Локализация каучука в растениях кок-сагыза

Каучук в растениях кок-сагыза находится главным образом в подземных органах в виде глобул в латексе, который образуется в млечных трубках. Первичная млечная система формируется с момента прорастания семени вблизи от ситовидных трубок. Каучук образуется в корешках сеянцев в первый же день прорастания семени независимо от освещения. Далее в результате работы камбия, энергично образующего элементы древесины и луба, и формирования вторичных тканей происходит оттеснение к периферии первичной коры с находящимися в ней млечниками. В возрасте одного месяца наступает сбрасывание первичной коры. Вторичная млечная система образует у трехнедельных сеянцев 2-3 круга, в которых млечные трубки расположены группами по 3-4. Каучука в растении в этот период мало, сахаров и инулина нет [1, 40]. В период бутонизации млечная система развита слабо, каучука в млечном соке содержится мало. Однако в это время появляется значительное количество инулина и сахаров. Инулин локализуется в клетках периферийной части коры, моносахара - в паренхимных клетках, прилегающих к млечным сосудам [2]. К периоду цветения млечные сосуды образуют 8-9 концентрических кругов. В наружных кругах группы состоят из 7-9, внутренних - из 5-7 млечников. Количество каучука в растении возрастает. Инулин локализуется в клетках паренхимы между группами млечных сосудов, сахара - в млечных трубках.

В период плодоношения продолжается дальнейшее формирование и рост млечной системы. Количество кругов млечных сосудов достигает 10-13, содержание каучука увеличивается, а смолистых примесей снижается. Содержание инулина также возрастает, он локализуется полосами между кругами млечников. Сахара обнаруживаются в паренхимных клетках и млечниках. К концу вегетации количество каучука несколько больше, чем в момент плодоношения. Содержание инулина доходит до 40-45\% (на сухую массу корня). Он заполняет почти все клетки паренхимы. Сахара локализуются в значительных количествах в млечных трубках [3]. 
На второй год вегетации в корнях кок-сагыза развивается внутренняя пробка и образуется «каучуковый чехол». Участки тканей, отрезанные пробкой от осевого цилиндра, отмирают, каучуковый чехол разрушается. Такой процесс происходит ежегодно, при этом отсекается вся вторичная кора предыдущего года вегетации $[23,43,44]$. Только у дикорастущих растений в условиях медленного распада чехла наблюдали корни с несколькими годичными чехлами [24]. Указанное явление обусловливает резкое колебание содержания каучука в корнях двухлетнего коксагыза в разные периоды вегетации.

\section{Свойства каучука из кок-сагыза}

Натуральный каучук представляет собой линейную, в основном цис-форму 1,4-полиизопрена с регулярной структурой $\left[-\mathrm{CH}_{2} \mathrm{C}\left(\mathrm{CH}_{3}\right)=\mathrm{CHCH}_{2}-\right]_{n-}$.<smiles>C/C=C(/C)CC/C=C(/C)CC/C(C)=C\CC</smiles>

Биосинтез каучука исследуют в основном на примере гевеи, но в последнее время стали изучать и другие культуры, образующие полиизопрен. Основные этапы формирования компонентов латекса вплоть до каучука такие: ацетил-СоА $\rightarrow$ ацетоацетил-СoA $\rightarrow$ 3-гидрокси-метил-глутарил-СoA $\rightarrow$ мевалонат $\rightarrow$ изопренилдифосфат $\rightarrow$ диметилаллилдифосфат $\rightarrow$ геранилдифосфат (C 10, монотерпеноиды) $\rightarrow$ фарнезилдифосфат (C 15 , сесквитерпеноиды) $\rightarrow$ цис-1,4 полиизопрен [51, 53, 54, 67, 70].

Терпены, в том числе каучук, являются конечными продуктами обмена веществ в кок-сагызе. Синтез каучука осуществляется из неспецифических ассимилянтов, оттекающих из листьев. Этот процесс происходит без участия солнечной энергии. Функции каучука в растении все еще не вполне понятны. Латекс у разных растений независимо от наличия или отсутствия каучука в нем выполняет защитные функции. По мнению А.А. Прокофьева [39], образующийся в растении каучук не несет какой-нибудь определенной функции. Его роль заключается в переводе возникающего в процессе обмена веществ изопрена в физически неактивное состояние. Есть основания считать, что каучук участвует в отложении запасных питательных веществ. Каучуковый «чехол» сбрасывается растением, когда запас питательных веществ в нем израсходован [34]. Зависимости между содержанием и качеством каучука, а также содержанием и степенью его полимеризации не обнаружено [19].

Натуральный каучук содержит 98\% изопентеновых групп, связанных по положениям 1 и 4 и 2\% по положениям 3 и 4. Среднечисловая молекулярная масса - 100-300 тыс., среднемассовая - 1,3-2,6 млн. Растворимость каучука в таких гидрофобных растворителях, как бензол, толуол, бензин, СНC13, СС14 и др., $-60-85 \%$. Плотность - 0,91 г/см3; температура стекленения - от -69 до $-74{ }^{\circ} \mathrm{C}$. Он кристаллизуется при охлаждении и деформировании (в недеформированном состоянии - при температурах от -50 до 20 ${ }^{\circ} \mathrm{C}$, с максимальной скоростью при $\left.-25{ }^{\circ} \mathrm{C}\right)$. Максимальная степень кристалличности - 30-40\%, темпе- ратура плавления кристаллической фазы - $15-40{ }^{\circ} \mathrm{C}$ в зависимости от условий кристаллизации $[11,58]$.

Для характеристики каучука пользуются средней молекулярной массой, зависящей от фракционного состава образца и методов ее измерения. Молекулярная масса каучука кок-сагыза, определенная вискозометрическим способом, составляет 150000 [28]. Для ускоренной оценки качества и количества каучука в растении предложена глазомерная балловая оценка по небольшим отрезкам из средней части корня, основанная на различии эластичности полученных при растирании пленок каучука, обработанных щелочью [19].

Свойства каучука кок-сагыза, выращенного в Ленинградской обл. (Пушкинские лаборатории ВИР), были изучены в лаборатории биомоделирования Воронежского института синтетического каучука в сравнении с каучуком гевеи. Образцы исследованы методами тонкослойной хроматографии, инфракрасной спектроскопии, дифференциально-термического анализа. Данные по всем показателям свидетельствуют об аналогичности каучуков кок-сагыза и гевеи [6].

Лабораторные испытания физических и химических свойств каучука кок-сагыза показали, что его высокое качество оправдывает крупномасштабное коммерческое производство и испытание шин, изготовленных из его каучука [71]. Молекулярная масса каучука кок-сагыза, составляющая $3 \times 105$ дальтон (выше, чем у каучука из гевеи и гваюлы), указывает на его высокое качество [64]. Американский патент (2004/044173) дает молекулярную массу в $2,2 \times 10^{6}$ дальтон.

Натуральный каучук технологически совместим с другими ненасыщенными каучуками, полиэтиленом, сополимерами стирола. При приготовлении резиновых смесей на основе натурального каучука используют серные, изоцианатные и другие вулканизующие системы, активные и неактивные наполнители (в т. ч. светлые и цветные), антиоксиданты, антиозонанты, пластификаторы и другие обычно применяемые ингредиенты. Изготовление и переработку смесей, вулканизацию изделий проводят на обычном оборудовании резиновых заводов. Натуральный каучук характеризуется уникальным комплексом технических свойств: высокими клейкостью и когезионной прочностью резиновых смесей; эластичностью, прочностью и сопротивлением раздиру резин (в т. ч. ненаполненных и наполненных неактивными наполнителями), хорошими сопротивлением росту трещин, морозо- и износостойкостью, тягово-сцепными свойствами [30]. Резины на основе натурального каучука противостоят действию большинства кислот (не являющихся окислителями), щелочей, растворов солей, но не стойки к действию масел и топлив. Натуральный каучук общего назначения применяют в производстве шин ( $60 \%)$, транспортерных лент, приводных ремней, рукавов, амортизаторов, прокладок, уплотнителей и др., клеев, эбонитов, электроизоляционных материалов, губчатых резин, резиновых изделий бытового, санитарно-гигиенического, медицинского, пищевого и спортивного назначения.

\section{Инулин}

Корни кок-сагыза содержат 25-45\% (от сухой массы) инулина. В настоящее время инулин добывают в основном из цикория и топинамбура, в которых его 
содержание составляет 10-12\%. Инулин $\left(\mathrm{C}_{6} \mathrm{H}_{10} \mathrm{O}_{5}\right)_{n}$, - полимер D-фруктозы. Это белый порошок, легко растворимый в горячей и трудно - в холодной воде. Молекулярная масса - 5000-6000 Да. Имеет сладкий вкус. При гидролизе под действием кислот и фермента инулазы образует D-фруктозу и небольшое количество глюкозы. Инулин может быть легко ферментирован в этанол.



Молекула инулина - цепочка из остатков фруктозы в фуранозной форме. Инулины различаются длиной полимерной цепи. Существуют низкомолекулярные инулины (средняя степень полимеризации - 10 и ниже) и высокомолекулярные инулины (средняя степень полимеризации - 20 и выше). Подобно крахмалу, инулин служит запасным углеводом. В рамках программы производства каучука США в 1946 г. был разработан и запатентован экспериментальный метод экстракции инулина из кок-сагыза. На первых этапах обработки сырья углеводы (главным образом инулин) растворяются горячей водой. Для экстракции могут быть использованы как свежие, так и высушенные корни [71].

Инулин широко используется в пищевой и фармацевтической промышленности. В пищевой индустрии он применяется для замены жиросодержащих веществ [27], а также служит исходным материалом для промышленного получения фруктозы. В медицине вещество используется как компонент БАД [http:/ demetra-holding.vdnh.ru]. Инулин не усваивается opганизмом, являясь растворимым пищевым волокном, обладающим пребиотическим эффектом. Чем выше средняя степень полимеризации, тем выше биологическая активность инулина. В пищеварительном тракте инулин проходит в неизменном виде через желудок и тонкий кишечник, а в толстом кишечнике ферментируется микрофлорой. Растительный инулин модифицирует микрофлору кишечника, содействуя развитию бифидобактерий; снижает уровень глюкозы в крови у диабетиков; улучшает обмен липидов, чем предотвращает возникновение осложнений сахарного диабета; снижает уровень холестерина, триглицеридов и фосфолипидов крови; снижает факторы риска сердечно-сосудистых поражений. Инулин выводит из организма токсины, соли и радионуклиды, улучшает работу желудочнокишечного тракта, что предотвращает возникновение онкологических заболеваний; оказывает иммуномодулирующее и гематопротекторное действие; улучшает усвояемость витаминов и минералов в организме (особенно $\mathrm{Ca}, \mathrm{Mg}, \mathrm{Zn}, \mathrm{Cu}, \mathrm{Fe}$ и $\mathrm{P}$ ) [http:// demetra-holding.vdnh.ru]. Приведенные свойства инулина позволяют называть его «растительным инсу- лином», хотя структура и механизм действия этих веществ разные. Как лечебно-профилактический и диетический продукт инулин применяется при сахарном диабете I и II типа, ожирении, атеросклерозе, ишемической болезни сердца, инфаркте миокарда, остеохондрозе, почечнокаменной и желчнокаменной болезни, запорах, иммунодефицитах, контакте с радионуклидами.

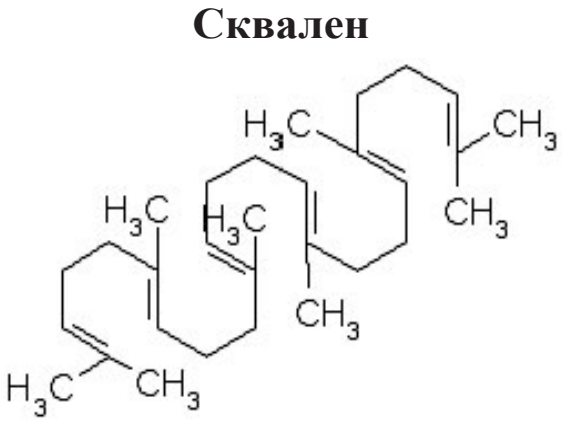

Среди углеводородов в млечном соке кок-сагыза обнаружен сквален - ациклический полиненасыщенный изопреноид. В чистом виде это бесцветная вязкая жидкость, молекулярная масса - 410,73; температура кипения $-242{ }^{\circ} \mathrm{C} / 4$ мм рт. ст.; легко растворим в диэтиловом и петролейном эфирах, $\mathrm{CCl}_{4}$, ацетоне, плохо - в холодном этаноле и $\mathrm{CH}_{3} \mathrm{COOH}$, не растворим в воде.

Название сквалена происходит от латинского squalus - акула, так как впервые он был обнаружен в печени акулы. Сквален содержится также в оливковом, хлопковом и льняном маслах; масле из зародышей пшеницы, во многих животных и растительных тканях [http://www.xumuk.ru/encyklopedia/2/4090.html].

Ультрафиолетовый спектр поглощения натурального каучука в области 200-250 нм подобен спектpy поглощения сквалена [http://www.center-oliteh.ru/ developments/kauchuk.html].

Сквален - промежуточное соединение в биосинтезе стероидов. Биосинтез сквалена осуществляется из мевалоновой кислоты, которая превращается в фарнезилпирофосфат и далее под действием скваленсинтетазы в присутствии тиамина - в сквален. Сквален - основной ингредиент липидного покрытия поверхности кожи, образованного секретом сальных желез и липидами, продуцируемыми кератиноцитами. От сквалена зависят целостность рогового слоя и эластичность, влажность и мягкость кожи, ее способность препятствовать проникновению микроорганизмов, токсинов, аллергенов оказывает антигрибковое и антибактериальное действие. Недостаток сквалена является одним из важнейших звеньев старения кожи. Косметические продукты с его использованием обладают пониженной аллергенностью. Сквален равномерно смешивающееся с водой, что не требует добавки вредных эмульгаторов или поверхностно активных веществ. (http://www.sunrise4you. $\mathrm{ru} /$ squalene.html).

\section{Перспективы современного использования кок-сагыза}

Опытные посевы кок-сагыза проводятся в Испании, США и Китае. В 2012 г. голландско-индийская компания «Аполло Вредестейн», бизнес-партнер консорциума по производству и использованию альтернативных каучука и латекса, состоящего из 10 
компаний восьми стран (Франция, Германия, Испания, Италия, Голландия, Чехия, Казахстан и США) разработала первый прототип автомобильных шин, изготовленных из выращенного в Европе источника каучука. В случае успешного испытания компания намеревается начать полномасштабное производство шин в 2015 г. Аналитическое подразделение английского издания «Экономист» оценивает добычу природного каучука в 10,9 млн тонн в год. Стоимость такого каучука - 32,6 млрд фунтов. Синтетического каучука получают в год почти 15 млн тонн, а его стоимость составляет 31,5 млрд фунтов. В настоящее время существуют серьезные опасения, что уже в 2020 г. спрос может превысить предложение на 20\%. Положение усугубляют падение производства натурального каучука, монопольное положение стран, где произрастает гевея, болезни растений, изменение климата, падение запасов нефти и т. д. Производители автомобильных шин, такие как «Бриджстоун», вкладывают в исследование и возможность коммерческого использования кок-сагыза и гваюлы большие средства. [http://www.agronews.ru/news/detail/125691].

\section{Литература}

\section{Список русскоязычной литературы}

1. Блохинцева ИИ. К вопросу об образовании каучука у кок-сагыза. Бот журн. 1939;24(4):265-72.

2. Блохинцева ИИ. К анатомии и микрохимии кок-сагыза. В кн.: Физиология и биохимия каучуконосов. М.: ГОНТИ; 1939. с. 56-70.

3. Блохинцева ИИ. Образование каучука у кок-сагыза. Вести с.-х. науки Техн культуры. 1940;(3):50-6.

4. Боссэ ГГ, Ильин ММ. Поиски источников каучука и гуттаперчи в СССР. Каучук и каучуконосы. 1953;2:136-7.

5. Булгаков СВ. Сравнительное испытание сортов естественной и экспериментальной селекции каучуконосов. В кн.: Купцов АИ ред. Селекция каучуконосных растений. М.: Сельхозгиз; 1937. с. 12-35.

6. Вахрушева ТЕ, Евдокимова ОА, Карчевская АВ, Сосновская НГ. Отечественные источники натурального каучука и перспективы их использования. Растениеводство, генетика и селекция технических культур. 1991;144:153-67.

7. Вахрушева ТЕ. Классификатор каучуконосного вида Taraxacum kok-saghyz Rodin (одуванчик кок-сагыз). СПб.; 1992.

8. Вахрушева ТЕ. Диагностика возбудителей грибных болезней и вредителей кок-сагыза. Методические указания. СПб.; 1993.

9. Вахрушева ТЕ, Кальян НГ, Низова ГК. Каталог мировой коллекции ВИР. Кок-сагыз. СПб.; 1994.

10. Вахрушева ТЕ. Кок-сагыз - источник ценного сырья для отечественной промышленности. Текстиль. 2003;5(7):16-8.

11. Догадкин БА. Химия эластомеров. М.; 1981.

12. Заботкина ЛВ. Особенности регенерации кок-сагыза. Агробиология. 1947;(5):67-78.

13. Ильин ММ. Каучуконосность флоры СССР. Каучук и каучуконосы. 1953;(2):9-104.

14. Как возделывать кок-сагыз. Ред.: Эйхфельд ИГ. Л.; 1949.

15. Кобелев ВК. Селекция каучуконосных растений. Т. 3. М- Л.;1937. с. 641-70.
16. Королева ВА. Межвидовая гибридизация роде Таraxacum. ДАН СССР. 1939;24(2):173-5.

17. Королева ВА. Внутривидовое разнообразие и его значение для преобразования кок-сагыза в культурное растение. Бот. журн. 1957;42(3):414-25.

18. Королева ВА. Об отношении кок-сагыза к температурному фактору. Труды по прикладной ботанике, генетике и селекции. 1958;31(3):288-298.

19. Коялович Н, Алпатьева М. Метод одновременного качественного и количественного определения каучука в корнях кок-сагыза. Научный отчет ВИР. М.: ОГИЗ-Сельхозгиз; 1945. c. 205-10.

20. Кутузова СН, Петросян ИА. Морфо-биологическое изучение кок-сагыза из коллекции ВИР. Труды по прикладной ботанике, генетике и селекции. 2011;167:125-32.

21. Культура каучуконосов в СССР. Ред.: Филиппов ДИ, Ничипорович АА, Аксельрод ДМ. М.: Сельхозгиз; 1948.

22. Лебедев АП. К морфологической изменчивости листьев у кок-сагыза. В кн.: Селекция каучуконосных растений. Т 1. М.: Сельхозгиз; 1937. c. 28-38.

23. Лейсле ВФ, Милютина СВ. Образование и сбрасывание «чехла» на корнях кок-сагыза августовских посевов. Доклады ВАСХНИЛ. 1938;(23-24):58-61.

24. Липшиц СЮ. Новый каучуконосный одуванчик Taraxacum kok-saghyz. М.-Л.: Госхимтехиздат; 1934.

25. Липшиц СЮ. Кок-сагыз. В кн.: Каучук и каучуконосы. Т. 2. М.: АН СССР; 1953. с. 153-72.

26. Макагон ВН. Проблема натурального каучука в СССР. В кн.: Каучук и каучуконосы. M.: АH CCCP; 1936. c. 127-70.

27. Матвеева ТВ, Корячкина СЯ, Дерканосова НМ. Способ снижения энергетической ценности кексовых и песочных изделий. Современные наукоемкие технологии. 2008;5:63-4.

28. Маштаков СМ. Гваюла (Вискозиметрическая характеристика каучука и физико-химические константы смол различных форм и сортов гваюлы). Каучук и резина. 1939;9:36-40. 
29. Маштаков СМ. Качественные изменения каучука в корнях кок-сагыза на втором году вегетации. ДАН СССР.1939;24(5):509-12.

30. Моисеев ВВ, Евдокимова ОА, Гуляева НА. Новые подходы к проблемам биосинтеза натурального каучука и модификация синтетических каучуков. Каучук и резина.1989;7:60-3.

31. Моисеева ВП. О продуктивности форм кок-сагыза, цветущих и не цветущих в первом году вегетации. Бот журн. 1960;45(8):1175-8.

32. Павлов НВ. Дикие полезные технические растения. М.; 1942. с. 640.

33. Поддубная-Арнольди ВА. Межвидовая гибридизация в роде Taraxacum // МОИП Отд биол. 1939;48(5-6):87-98.

34. Половенко ИС, Филиппов ДИ, Правдин ФН, Фурман ЛШ. Кок-сагыз. М.; 1950.

35. Попцов АВ. Биология прорастания семян кок-сагыза. В кн.: Биология прорастания семян каучуконосов. М.: ГОНТИ; 1938. с. 3-5.

36. Попцов АВ. О некоторых особенностях биологии прорастания семян кок-сагыза. ДАН CCCP. 1949;68(3):609-11.

37. Прокофьев АА. Анализ каучуконосных растений. М.: ОНТИ; 1936.

38. Прокофьев АА. Состояние каучука в растениях. ДАН СССР. 1940;28(9):809-11.

39. Прокофьев АА. Локализация, образование и состояние каучука в растениях. М.-Л; 1948.

40. Прокофьев АА, Сафронов ГП, Мазилкина МК. О латексе корневых каучуконосов. ДАН СССР. 1948;59(9):1661-4.

41. Прокофьев АА. Состояние каучука в растениях. Каучук и каучуконосы. 1953;2:107-35.

42. Прокофьев АА, Люкова ЛА. Развитие млечной системы в зависимости от возраста и условий минерального питания растений. Физиология растений. 1956;3(1):23-31.

43. Руденская БЯ. Об образовании «чехла» на корнях кок-сагыза. В кн.: Физиология и анатомия каучуконосов. М.: Сельхозгиз; 1936. c. 110-29.

44. Руденская БЯ. Развитие млечной системы как фактор накопления каучука в корнях коксагыза. ДАН СССР. 1938;20(5):401-4.

45. Скоропанов СГ, Бельский ББ, Маштаков СМ. Кок-сагыз. Руководство по культуре коксагыза на торфяных почвах. Минск: Изд. АН БССР; 1951.

46. Филиппов ДИ. Культура кок-сагыза. Каучук и каучуконосы. 1953;2:173-219.

47. Янушевич 3В. Образования каучука у кок-сагыза как функция хода его биологического развития. Труды по прикладной ботанике, генетике и селекции. 1948;28(1):175-184.

\section{Общий список литературы/Reference list}

1. Blokhintseva II. [On rubber resin generation in kok-saghyz]. Bot Zhurn. 1939;24(4):265-72. (In Russ.)

2. Blokhintseva II. [On anatomy and microchemistry of kok-saghyz]. In: Fiziologiya i Biokhimiya Kauchukonosov. Moscow: GONTI; 1939. p. 56-70. (In Russ.)
3. Blokhintseva II. [Rubber resin generation in kok-saghyz]. Vesti Selskokhoziaysvennoy Nauki Tekhnicheskiye Kultury.1940;(3):50-6. (In Russ.)

4. Bosse GG, Il'in MM. [Searching for sources of rubber and gutta-percha in the USSR]. Kauchuk i Kauchukonosy.1953;2:136-7. (In Russ.)

5. Bulgakov SV. [Comparative testing of rubber producing plant varieties resulting from artificial and natural selection]. In: Kuptsov AI, ed. Selektsiya Kauchukonosnykh Rasteniy. Moscow: Selkhozgiz; 1937. p. 12-35. (In Russ.)

6. Vakhrusheva TYe, Yevdokimova OA, Karchevskaya AV, Sosnovskaya NG. [Domestic sources of natural rubber and prospects for making use thereof]. Rasteniyevodstvo, Genetika i Selektsiya Selskokhoziaystvennykh Kultur.1991;144:153-67. (In Russ.)

7. Vakhrusheva TYe. Klassifikator Kauchukonosnogo Vida Taraxacum Kok-saghyz Rodin (oduvanchik kok-sagyz). Saint Petersburg; 1992. (In Russ.)

8. Vakhrusheva TYe. Diagnostika Vozbuditeley Gribnykh Bolezney i Vrediteley Kok-sagyza Metodicheskiye Ukazaniya. Saint Petersburg; 1993. (In Russ.)

9. Vakhrusheva TYe, Kal'yan NG, Nizova GK. Katalog Mirovoy Kollektsii VIR Kok-sagyz. Saint Petersburg; 1994. (In Russ.) (In Russ.)

10. Vakhrusheva TYe. Kok-sagyz - Istochnik Tsennogo Syr'ya Dlia Otechestvennoy Promyshlennosti. Tekstil. 2003;5(7):16-8. (In Russ.)

11. Dogadkin BA, Dontsov AA, Shershnev VA. Khimiya Elastomerov. Moscow: Khimiya; 1981. (In Russ.)

12. Zabotkina LV. [Characteristics of kok-saghyz generation]. Agrobiologiya. 1947;(5):67-78. (In Russ.)

13. Il'in MM. [Rubber producers among USSR flora]. Kauchuk i Kauchukonosy. 1953;(2):9-104. (In Russ.)

14. Eykhfeld IG, ed. Kak Vozdelyvat' Koksagyz. Leningrad; 1949. (In Russ.)

15. Kobelev VK. Selektsiya Kauchukonosnykh Rasteniy Vol 3. Moscow-Leningrad; 1937. p. 641-70. (In Russ.)

16. Koroleva VA. [Interspecies hybridization within the genus Taraxacum]. DAN SSSR. 1939;24(2):173-5. (In Russ.)

17. Koroleva VA. [Intraspecies variability and its significance for transformation of kok-saghys into cultivated plant]. Bot Zhurn. 1957;42(3):414-25. (In Russ.)

18. Koroleva VA. [On kok-saghyz tolerance to temperature]. Trudy po Prikladnoy Botanike Genetike i Selektsii. 1958;31(3):288-98. (In Russ.)

19. Koyalovich N, Alpatyeva M. [A method for simultaneous qualitative and quantitative determination of rubber resin in kok-saghyz roots]. In: Nauchnyi Otchet VIR. Moscow: OGIZ-Selkhozgiz; 1945. p. 205-10. (In Russ.)

20. Kutuzova SN, Petrosyan IA. [Morphobiological studies of kok-saghyz from VIR Collection. Trudy po Prikladnoy Botanike Genetike i Selektsii. 2011;167:125-32. (In Russ.)

21. Filippov DI, Nichiporovich AA, Akselrod DM. Kultura Kauchukonosov v SSSR. Moscow: Selkhozgiz; 1948. (In Russ.) 
22. Lebedev AP. [On the morphological variability of leaves in kok-saghyz]. In: Selektsiya Kauchukonosnykh Rasteniy. Moscow: Selkhozgiz; 1937. Vol. 1, p. 28-38. (In Russ.)

23. Leysle VF, Milyutina SV. [Formation and shedding of a "sack" on the roots kogsaghyz seeded in August]. Doklady VASKhNIL.1938;(23-24):58-61. (In Russ.)

24. Lipshits SYu. Novyi Kauchukonosnyi Oduvanchik Taraxacum kok-saghyz. Moscow-Leningrad: Goskhimtekhizdat; 1934. (In Russ.)

25. Lipshits SYu. [Kok-saghyz]. Kauchuk i Kauchukonosy. 1953;2:153-72. (In Russ.)

26. Makagon VN. [Natural rubber problem in the USSR]. Kauchuk i kauchukonosy. 1936:127-70. (In Russ.)

27. Matveyeva TV, Koryachkina SYa, Derkanosova NM. [A method for calorie content reduction in cakes and cookies]. Sovremennye Naukoyemkiye Tekhnologii. 2008;5:63-4. (In Russ.)

28. Mashtakov SM. [Viscosimetric characterization of rubber and physicochemical constants of resins from different forms and varieties of guayule]. Kauchuk i Rezina. 1939;9:36-40. (In Russ.)

29. Mashtakov SM. [Qualitative changes in rubber resin in the roots of kok-saghyz at the second year of its vegetation]. DAN SSSR. 1939;24(5):509-12. (In Russ.)

30. Moiseyev VV, Yevdokimova OA, Gulyayeva NA. [Novel approaches to the problems of natural rubber biosynthesis and synthetic rubbers modification]. Kauchuk i Rezina.1989;7:60-3. (In Russ.)

31. Moiseyeva VP. [On the productivity of kok-saghyz forms that do flowering or do not flower at first year of vegetation]. Bot Zhurn.1960;45(8):1175-8. (In Russ.)

32. Pavlov NV. Dikiye Poleznye Tekhnicheskiye Rasteniya. Mocow; 1942. (In Russ.)

33. Poddubnaya-Arnoldi VA. [Interspecies hybridization in the genus Taraxacum]. MOIP Otd Biol. 1939;48(5-6):87-98. (In Russ.)

34. Polovenko IS, Filippov DI, Pravdin FN, Furman LSh. Kok-Sagyz. Moscow; 1950. (In Russ.)

35. Poptsov AV. [Biology of kok-saghys seeds germination]. In: Biologiya Prorastaniya Semyan Kauchukonosov. M.: GONTI; 1938. p. 3-5. (In Russ.)

36. Poptsov AV. [On some characteristics of the biology of kok-saghyz seeds germination]. DAN SSSR.1949;68 (3):609-11. (In Russ.)

37. Prokofyev AA. Analiz Kauchukonosnykh Rasteniy. Moscow: ONTI; 1936. (In Russ.)

38. Prokofyev AA. [Rubber resin state in plants]. DAN SSSR. 1940;28( 9):809-11. (In Russ.)

39. Prokofyev AA. Lokalizatsiya, Obrazovanie i Sostoyanie Kauchuka v Rasteniyakh. MoscowLeningrad; 1948. (In Russ.)

40. Prokofyev AA, Safronov GP, Mazilkina MK. [On latex of rooted rubber-producing plants]. DAN SSSR. 1948; 59(9):1661-4. (In Russ.)

41. Prokofyev AA. [The state of rubber resin in plants]. Kauchuk i Kauchukonosy. 1953;2:107-35.

42. Prokofyev AA, Lyukova LA. [Latex system development depending on plant age and mineral nutrition]. Fiziologiya Rasteniy. 1956;3(1):23-31. (In Russ.)
43. Rudenskaya BYa. [On the formation of a "sack" on the roots of kok-saghyz]. In: Fiziologiya i Anatomiya Kauchukonosov. M.: Selkhozgiz; 1936. p. 110-29. (In Russ.)

44. Rudenskaya BYa. [Latex system development as a factor of rubber resin accumulation in kok-saghyz roots] DAN SSSR. 1938;20(5):401-4. (In Russ.)

45. Skoropanov SG, Belskiy BB, Mashtakov SM. [Kok-saghyz]. In: Rukovodstvo po Kulture Kok-Sagyza na Torfyanykh Pochvakh. Minsk : Izdatelstvo AN BSSR; 1951. p. 155.

46. Filippov DI. [Kok-saghyz culture]. Kauchuk i Kauchukonosy. 1953;2:173-19. (In Russ.)

47. Yanushevich ZV. [Rubber resin formation in kok-saghyz as a function of the course of its biological development]. Tudy po Prikladnoy Botanike, Genetike I Selektsii.1948;28(1):175-84. (In Russ.)

48. Anonymus. Russian rubber plants. Nature. 1945;155:229-30.

49. Backhaus RA. Rubber formation in plants a mini-review. Israel J Bot. 1985;34:283-93.

50. Bousquet $\mathrm{J}$ et al. Natural rubber latex allergy among health care workers: a systematic review of the evidence. J Allerg Clin Immunol. 2006; 118:447-54.

51. Bouvier $F$ et al. Biogenesis, molecular regulation and function of plant isoprenoids. Prog Lip Res. 2005;44:357-429.

52. Cornish K. Similarities and differences in rubber biochemistry among plant species. Phytochem. 2001;57:123-34.

53. Cornish K, Xie W. Natural rubber biosynthesis in plants: Rubber Transferase. Meth Enzymol. 2012;515:63-82.

54. Fatland BL et al. Reverse genetic characterization of cytosolic acetyl-CoA generation by ATP-citrate lyase in Arabidopsis. Plant Cell. 2005;17:182-203.

55. Freundlich H, Hauser EA. Zur Kolloidchemie der Kautschukmilchsäfte. Zsigmondy Festschrift Erg. Koll. Zs.1925;36:15-36.

56. Heim S. Kalorien, Kautschuk, Karrieren. Pflanzenzüchtung und Landwirtschaftliche Forschung in Kaiser-Wilhelm-Instituten 1933-1945. Goettingen: Wallstein Verlag; 2003.

57. Kekwick RGO. Latex and laticifers. In: Encyclopedia of Life Sciences. Wiley and Sons; 2001. DOI: 10.1038/npg.els.0000913.

58. Kirk-Othmer Encyclopedia of Chemical Technology. 1982;20(3):468-91.

59. Kirschner J, Stěpanek J. Dandelions in Central Asia: A taxonomic revision of Taraxacum sect. Leucantha. Preslia. 2006;78:27-65.

60. Kirschnr J et al. Available ex situ germplasm of the potential rubber crop Taraxacum koksaghyz belongs to a poor rubber producer, $\mathrm{T}$. brevicorniculatum (Compositae-Crepidinae). Genet Resource Crop Evol. 2013;60:455-71.

61. Kupzow AJ. Theoretical basis of plant domestication. Theor Appl Genet. 1980;57:65-74

62. Langeland E. A new rubber particle count in Hevea Latex. Ind Eng Chem. 1936;8(3):174-5.

63. Malecka J. Cyto-taxonomical and embryological investigations on a natural hybrid between Taraxacum kok-saghyz Rodin and $\mathrm{T}$. officinale 
Web. and their putative parent species. Acta Biol Cracoviensia. 1971;16:179-97.

64. Mooibroek H, Cornish K. Alternative sources of natural rubber. Appl Microbiol Biotechnol. 2000;53:355-65.

65. Polhamus LG. Rubber - Botany, Production, and Utilization. Leonard Hill Ltd.; 1962.

66. Siler DJ et al. Composition of rubber particles of Hevea brasiliensis, Parthenium argentatum, Ficus elastica, and Euphorbia lactiflua indicates unconventional surface structure. Plant Physiol Biochem. 1997;35:881-9.

67. Sirinupong $\mathrm{N}$ et al. Molecular cloning of a new cDNA and expression of 3-hydroxy-3-meth-
ylglutaryl-CoA synthase gene from Hevea brasiliensis. Planta. 2005;221:502-12.

68. Tysdal HM, Rands RD. Breeding for disease resistance and higher rubber yield in $\mathrm{He}$ vea, guayule and kok-saghyz. J Amer Soc Agron. 1953;42:234-43.

69. Van Beilen JB et al. Alternative sources of natural rubber. York: CPL Press; 2006.

70. Van Beilen JB, Poirier Y. Establishment of new crops for the production of natural rubber. Trends Biotechnol. 2007;25(11):522-9.

71. Whaley JS, Bowen WG. Russian dandelion (koksaghyz). An emergency source of natural rubber. Washington. DC: USDA; 1947.

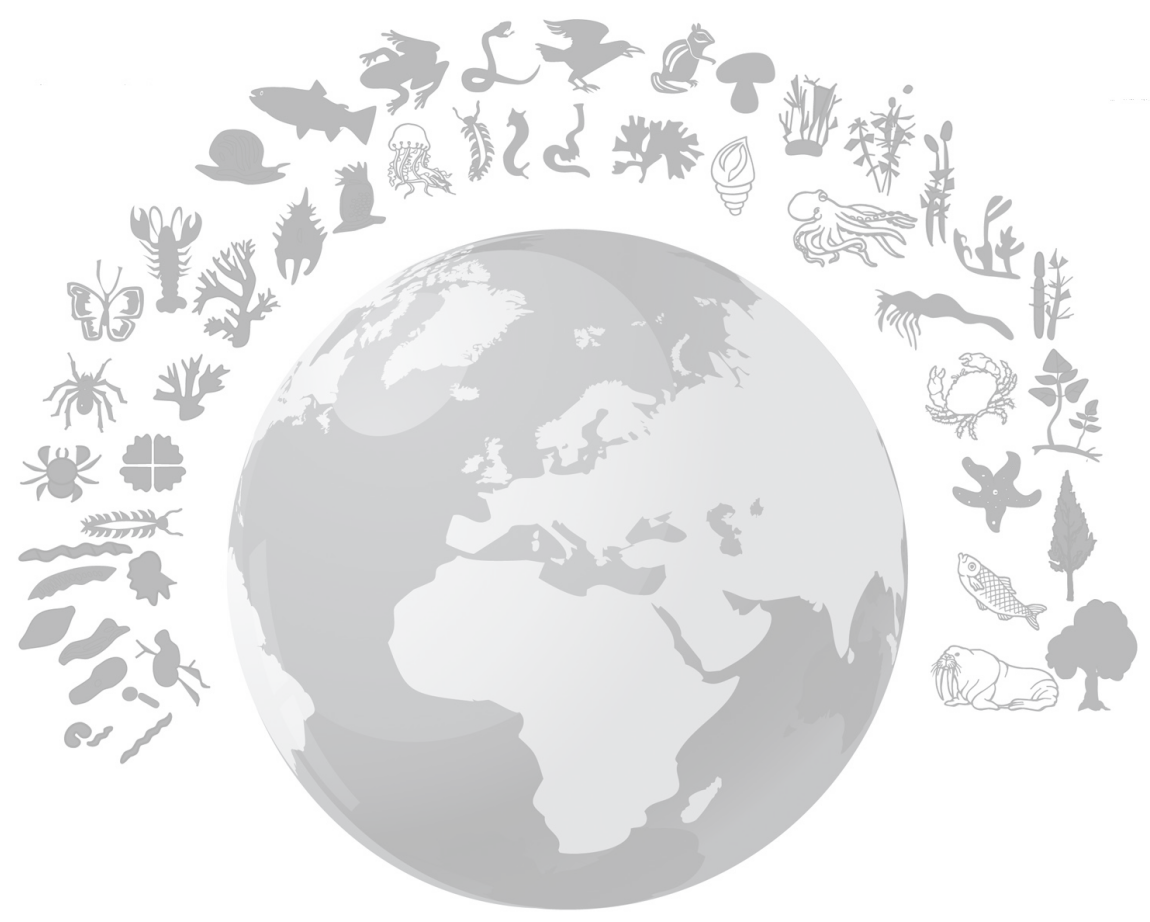

